\title{
Building a Culture of Peace and Multiculturalism in the World of Education
}

\author{
Abd. Rahman Mas'ud, \\ PhD, Religious Research, Development and Training Agency, MoRA Indonesia \\ walisongos@yahoo.com
}

\begin{abstract}
Building a culture of peace in the education space is a joint task for all Indonesian people. The strategic position of education is expected to be the center of forging a spirit of togetherness in diversity. Teachers / lecturers and other academicians need to continue to mainstream "peaceful culture" and the spirit of multiculturalism in the education space. Creating a school climate and culture that is safe, comfortable, peaceful and respects differences is the main task and responsibility of the educational community through various approaches, namely intra-curricular, co-curricular, and extra-curricular.
\end{abstract}

Keywords

Peace Culture, Religious Education, Schools

Article Received: 10 August 2020, Revised: 25 October 2020, Accepted: 18 November 2020

\section{Introduction}

Peace, is the core message of the prophets, and apostles since the beginning of human creation. Therefore "efforts to maintain peace" or the suggestion to live peacefully is not new. It is a classic thing that is constantly updated according to the context and situation of the era. Articulatively, the mainstreaming of 'culture of peace' and multiculturalism arises in the midst of situations of violence, tyranny, oppression and other things that violate human rights.

In modern era, after the 2nd World War, the concept and movement 'Culture of Peace' was first introduced at an international conference "Congress on Peace in the Minds of Men" in 1989, in the city of Côte d'Ivoire. The meeting recommended that UNESCO as an International body of the United Nations (UN) develop a culture of peace based on universal values, such as: respect for the right to life, freedom, justice, solidarity, tolerance, human rights and equality between men and women. The momentum coincided with the international situation that marked the end of the cold war and the collapse of the Berlin wall in Germany.

In the UNESCO conception, peace is broadly interpreted. 'Peace is more than an absence of war. It means justice and equity for all as the basis for living together in harmony and free from violence, now, but even more so for our children and succeeding generations'. The word peace means more than 'being free from war'. Peaceful, meaning justice and equality for all, as a foundation for living together harmonically and free from violence, both in the present, or for children generations to come.

Following the meeting in Ivory Coast, in 1992 UNESCO's Executive Board established a special program for Peace Culture as part of the United Nations peacekeeping efforts. In 1994, the first 'International Forum on the Culture of Peace' was held in San Salvador (El Salvador). Continued in 1995, UNESCO introduced the concept of 'Culture of Peace' in its medium-term strategic program (1996-2001). And throughout that period (1996-2001), the United Nations has sponsored a series of activities on Culture of Peace, involving various NGOs, social organizations, the media, the press, religious leaders, in various countries. At its peak, in 1998, the United Nations declared 2001-2010 as an International Decade for a Culture of Peace and Non-Violence for the Children of the World.

Indonesia has experienced a series of physical violence and civil war, such as: in Aceh (Sumatra), Sampit (Kalimantan), Poso (Sulawesi), and Ambon - Ternate (Maluku). Physical violence leaded religious teachings and religious people to take actions that are condemned by religion itself. This experience was a historical trauma, and does 
not need to be repeated. Various attempts were made by various parties to reconcile those who had continued conflicts. Various social institutions (NGOs) oriented to the issue of conflict resolution, took to the field to carry out work of assistance and action research to resolve conflicts. Educational and training institutions, busy conducting counseling, therapy and handling of trauma to children in post-conflict areas. Maximum efforts were placed in the education sector to localize periods of conflict, not to be prolonged and to descend in the next generation. Education must break the chain of revenge and hatred between conflict groups, so that it is not passed down to students who will become the next generation of the Indonesian nation.

In order to respond to these dynamics, center for research and development of religious and religious education, research and development agency and education and training of the ministry of religion of the republic of Indonesia, has carried out a series of programs and activities in order to oversee the nation's policy in building a culture of peace and maintaining diversity in Indonesia. Some of them are: Interfaith teacher education dialogue program, book review of Preaching Smiling Islam, symposium on the role of religion in building a culture of peace, and Symposium on Religious Education, and so on.

\section{Literature Review}

\section{Peace Thesis and Clash of Civilizations}

Samuel Huntington predicted a clash of civilizations would occur. According to Huntington, there are 10 major civilizations of the world that will experience collisions, including Islamic civilization vis a vis with the West. In fact, he said that Islamic civilization experienced the most collisions, not only with the West, but also with other major civilizations. Huntington's thesis struck the world. Academics and experts in the field of civilization suddenly criticized the work as thoughts that poisoned the world. Instead of inspiring world peace, Huntington's thesis instead opens the gap for war between humanity to widen.

One of these criticisms of Huntington was made by Abdurrahman Mas'ud through his work
Preaching Smiling Islam. According to Prof. Dur, Huntington has over generalized West and Islam. In fact, not every West and Islam face each other diametrically in conflict-filled sociological conditions. Too many attempts at civilizational dialogue bring the West and Islam together. One that cannot be denied is the existence of intensive cooperation in the fields of culture and education as a base for the development of civilization. This is indicated by the high interest of Muslim countries to study in America.

The Clash of Civilization (CoC) view, must be replaced with cross culture understanding (CCU). To realize the CCU, the following steps are needed (1) To bridge the gap between the Muslim world and Western Civilization, and (2) To compare between Islamic and Western thoughts objectively and critically. Implementatively, the concept of cross culture understanding will manifest through tolerance and mutual coexistence or in Masud's terms Tolerance and Coexistence.

This thinking is in line with Linda Kingiii's view, which states that "an intercultural and interfaith for ethics Education (2008) reported that The Constitution of UNESCO states that the Organization's principal purpose is to "contribute to peace and security by promoting collaboration among the nations through education, science and culture in order to further universal respect for justice, for the rule of law and for human rights and fundamental freedoms which are affirmed for the people of the world, without distinction of race, sex, language and religion".

\section{The Role of Educational Institutions}

School becomes a place pinned hope for children. Because socially, it becomes the first place for a child to socialize and mingle with peers who have differences and uniqueness each. In accordance with the principle of individual humanity, that each person is unique, both because of the family's economic, social and cultural background, and religion, even because of the biological roots passed down by his parents. The uniqueness of each child is expressed in such a way which then gives birth to various charms of difference in the school environment. These differences can be a trigger for conflict which is 
then expressed into bullying and violence, or can be a trigger for friendship. Both forms of behavior have the same chance of occurrence, depending on the basic values, culture, and climate of the school created by the community and the academic community at the school.

The teacher as the host in the school in charge of managing cultural values and the school climate either through learning in the classroom or learning outside the classroom, has the main role to direct the behavior of school children more likely to permeate and practice a culture of peace, friendship in responding the differences that exist between students. School climate is formed by factors such as: school norms and rules, forms of relations between actors such as students, teachers, staff and school leaders, as well as relationships with actors and factors outside of school, very influential on student achievement and attitudes, even on the attitudes and motivations of teachers in teaching.

Many research reports either in the form of a thesis, or a dissertation that explain the relationship between children's perceptions of the school climate with learning motivation or towards learning achievement. As an example; Prasetyo, found that the school climate variable contributed $66 \%$ to the learning motivation of Class X students of SMA K 1 Metro Kibang in the 2014/2015 Academic Year. Other research results also show a significant relationship between school climate and the learning outcomes of students of class XII of SMK Negeri 2 Wonosobo in the academic year 2011/2012. The effect of the school climate as described above, is very reasonable. Because in a safe, comfortable and peaceful school, it will encourage the smooth teaching and learning process, both individually and in groups in the classroom.

\section{Teacher Position and Religious Education}

Socially, students who attend school must adhere to a certain religion derived from the family (parents). Religion becomes one of the vertices of children's identity. And substantively, the religion (which is adhered to by students) gives messages of kindness to the child. It happened at home before the child entered school. Many 'good' behaviors and habits of students that have been formed on the basis of their religion. Many problems can be solved through religious channels. But social development that occurs makes religious understanding among teenagers or students tend to be degraded by various nonreligious activities, thus unconsciously alienating religious values in the lives of children. Without realizing it, religion has not become the basis for attitude and behavior.

However, at the same time, the community still (always) gives the stereotype that the deviant behavior of adolescents is a mistake or lack of religious teachers. Religious teachers and religious education subjects at school often become the 'scapegoat' of deviant social behavior. That matter it can also be interpreted as a sign of the high expectations of the community towards religious education. The stereotype must be a driver and trigger to improve the performance of practitioners of religious education in schools.

Relating to a culture of peace and non-violence, religion has the potential to be used positively or negatively, depending on the person. Religious differences that have become the reality for the life of the nation, community and state in Indonesia if not understood properly and wisely by the community, can be the basis for indoctrination to justify someone's actions hostile to a religion different from the one he professes. Religion often triggers conflict and violence in Indonesian society, as a result of mistakes and lack of understanding of the teachings of the religion being adhered to. To set things right, a figure who understands religion and has a good national outlook is needed.

Religious education in schools is one of the instruments of the state in building religious understanding (especially and at least to schoolage students) in harmony with the ideals and goals of the country. Religious education in schools must fulfill its minimum function, namely 'maintaining peace and harmony in inter and interreligious relations'. And in that context, religious teachers are state agents in building a culture of peace through religious education. To fulfill this role, GPA must have multiculturalism insight and knowledge, in addition to understanding the nature and essence of religious 
teachings that are adhered to and taught to students.

Multiculturalism is the term that best represents the picture of Indonesia. There is no most appropriate expression to provide a description of the condition of Indonesia's reality other than by calling it a plural state in its true meaning. Multiculturalism has become sunatullah, the will of God given, so that opposing it is the same as opposing God who has willed by His creation. Understanding and appreciation of the multiculturalism facts that exist in Indonesia, will make it easier for teachers to make peace with themselves and their different environments. Agreeing and letting something be practiced and believed by others, even though it is different from understanding logic and common sense. This attitude can be referred to as 'agree in disagrement'.

With religious understanding, nationalism insight, and multiculturalism, religious education teachers can become personal dialogical', namely people who have the mental capacity to dialogue with various parties of different religions, cultures and personalities. Dialogical personal characteristics include: 1. Whole and authentic. Whole means giving a response to others with the whole person, not with a half-person, he is talking wholeheartedly. Said to be authentic because of someone respect others as individuals, not use them for personal gain. 2. Open. He is willing and able to express himself to others, willing and able to hear and accept other people's expressions, even criticism. 3 Discipline. $\mathrm{He}$ adheres responsibly to the rules of dialogue. He talks if there is something to be said or done if there is something that must be resolved without having to leave the context of the conversation.

From various literary exposures above, it is seen how important a culture of peace and multiculturalism is presented in the world of education.

\section{Research Method}

This paper is the result of policy research, which is about government policies and programs in building a culture of peace in Indonesia. The Ministry of Religion of the Republic of Indonesia through the Research and Development Center, Research and Development Agency and the Training Center became the research locus, where in the past decade has carried out a series of programs related to a culture of peace. Data was obtained from a collection of ideas and writing documents made in the context of implementing a culture of peace program, as well as reports on workshops, or seminars held in order to strengthen the culture of peace in Indonesia. Some of the important documents analyzed were as follows. Interfaith teacher education dialogue programx; book review Preaching Smiling Islam: Dialogue on Islamic and Western Humanity; symposium on the role of religion in building a culture of peace. Educational Symposium Religious.

\section{Result and Finding}

From the results of the document search activities that have been carried out by the Center for Research and Development of Religious and Religious Education, Research and Development and Education and Training Agency, found a series of activities that intersect with the program of Building a Culture of Peace and multiculturalism in the Education Room.

\section{Symposium on the Role of Religion in Building a Culture of Peace}

The International Symposium, "The Strategic Role of Religious Education in The Development of Culture of Peace," which was held by the Center for Religious and Religious Education in Bogor in 2012, invited key speakers, including from the United States, the Philippines and Namibia, with participants from various ASEAN MABIMS countries.

One of the recommendations agreed upon by the Symposium was the need to hold a Interfaith Teacher Education Dialogue in the context of developing a culture of peace in schools. The recommendation arises from various convincing arguments that religious education can play a strategic role in the development of a peaceful cultural education in schools. However, this role cannot be maximally carried out due to the reality, such as: (1) peaceful cultural education has been carried out in schools but has been carried out sporadically and is highly dependent on the 
initiative of the principal; (2) peace culture education is not explicitly included in the school curriculum; and (3) lack of coordination between schools and government to develop peaceful cultural education.

The organization of Dialogue Across Religious Education Teachers is also in line and appropriate with and supports the implementation of the Ministry of Religion's vision of "the realization of Indonesian people who are religious, advanced, prosperous, and intelligent as well as mutual respect among fellow believers in the life of society, nation and state in one Unitary State of Indonesia. The Unity of Indonesia, "and the mission of the Ministry of Religion, including improving the quality of harmony in religious life.

\section{Dialogue across Teachers of Religious Education}

The organization of the Dialogue Across of Religious Education Teachers is important given the potential for intolerant religious attitudes among students and even teachers in schools. Although the number of intolerance attitude is not so large, but this potential must be anticipated well. The potential for intolerant religious attitudes as found in research conducted by the 2012 Religious and Religious Education Research and Development Center on the diversity of high school students covering the entire island of Java and Sulawesi found this potential. The 2014 findings on the religious attitudes of religious education teachers and students in Central Sulawesi (three districts / cities) and West Kalimantan (3 districts / cities) which included 18 high schools, found that $5.3 \%$ of religious education teachers did not agree to be friends with people who different religions. The same thing was found in students as many as $2.7 \%$. The results of a poll conducted by the Kompas Research and Development Agency published May 13, 2015, found that $17.9 \%$ tolerance among religious communities in Indonesia was getting weaker.

In addition, various groups and components of the nation revealed his concern is that the values of diversity as a multicultural nation have lately begun to weaken. This was very prominent when the 'democratic party' took place such as regional head elections and general elections.

To overcome this problem, it is necessary to have planned and measured efforts to strengthen the harmony of religious life. Therefore, Dialogue Across Teachers of Religious Education followed by concrete action is seen as important and needs to be developed. The Dialogue activities have been held from 2013 to 2017 in the Bangka Belitung Islands Province, West Kalimantan, Central Sulawesi, South Sumatra, Central Java, North Sumatra, East Nusa Tenggara and Bali.

This dialogue has a goal, 1) the creation of an ideal religious education learning for the solid insight of nationalism and the Unitary Republic of Indonesia; 2) fostering a culture of peace for religious education teachers; 3) improving the quality of religious education in developing a culture of peace and multicultural education, and; 4) increasing awareness of the importance of religious education and the smooth communication between religious education teachers through forums that are formed and agreed upon together. Interfaith Dialogue of Religious Education Teachers that have been implemented produces Guidelines for Interfaith Dialogue of Religious Education Teachers Peaceful Culture Development in Schools and Module for Peaceful Culture Development Through Religious Education in Schools. The Dialogue Guidelines can be used as a reference for the Ministry of Religion or the Office of Education in organizing Dialogue Across Teachers of Religious Education.

Meanwhile, the Peace Culture Development Module can be used as a reference for schools, especially religious education teachers develop a culture of peace for students. All participants were provided with materials about respecting life; ending violence; full appreciation of all basic human rights and independence; building commitment to the peaceful resolution of conflicts; respecting and promoting equal rights; respect the principles of freedom, justice, democracy, tolerance, solidarity, and cooperation; and respect for diversity and cultural differences.

\section{Peaceful Cultural Action}


The peaceful cultural education action plan was a follow-up to the dialogue activities between religious education teachers, namely: 1) visiting and cleaning houses of worship (churches, mosques, temples, and vihara); 2) live-in to a religious education institution (islamic boarding school, seminary, temple, vihara and the like); 3) shared social services across religions; 4) sharing communication and information interfaith students to discuss social problems; 5) antiviolence campaign; 6) camp with interfaith students, 7) a parade of harmony every January 3 or a parade of tolerance every November $16 ; 8$ ) the competition makes up short stories and read poems about living peacefully.

The results of the implementation of the Dialogue were indeed not immediately visible in a short time. Because to form attitudes and moreover become a culture in a person, it took time. However, from the monitoring and evaluation activities as well as assistance to the implementation of peaceful cultural action plans in dialogue participating schools in such provinces, information was obtained that schools, students' parents, and the community strongly supported peaceful cultural education activities. The concrete manifestation of school support is to allow facilities and infrastructure owned by schools to be used by students to carry out peaceful cultural education activities through religious education. Schools increasingly respect differences. From other teachers, responses were also obtained that interactions between students of different religions are now more fluid, not awkward and not insulated, students are very happy to get to know, and understand other religious beliefs, and increasingly appreciate ways worship other religions. Not only students, parents are happy to know that their children are able to understand the diversity of religions, so they are willing to support the implementation of a peaceful cultural education conducted by schools.

In addition, local religious leaders support and appreciate interfaith student visits to different houses of worship.

\section{Religious Education Symposium}

In order to prepare the nation's young generation to face a demographic bonus ahead of 100 years of Indonesia (Indonesia Gold, 2045), the Ministry of Religion's Research and Development Agency considers that it is necessary to carry out dialogue across religious education institutions to formulate problems as well as solutions and recommendations related to the development of social reality and the speed of information technology which influences the development of socio-cultural values.

Several religious education institutions are present to provide practical best in developing the value of religious moderation in religious education institutions. Present to represent Islamic religious education institutions Tebuireng Islamic Boarding School (Islam), Malang Seminary (Catholic), Wonogiri Christian Theological High School (Catholic), Pasula Kula Bali (Hindu) Teachers, Hindu Global Kindergarten (buddha). This activity was attended by 120 religious interfaith practitioners.

This activity resulted in the formulation including: 1) the need for mainstreaming the development of religious moderation education in the environment of religious education institutions; 2) the need for cooperation between religious education institutions in developing moderate and tolerant religious understanding; 3 ) it needs joint activities in developing an attitude of togetherness among religious people; 4) it is necessary to increase the number of visits between religious education institutions to create empathy among fellow organizers of religious education institutions; 5) it is necessary to utilize the development of information technology (IT) in supporting the development of moderate attitudes and technological literacy in the organization of religious education institutions.

\section{Action Research on Building Equality in Rote, East Nusa Tenggara}

In the context of community development in $3 \mathrm{~T}$ areas (Behind, Outermost, Deepest), the Research and Development Agency of the Ministry of Religion conducts action research involving University Students Religious College along with their community service program. One of the targets of action research was the people of Rote (Indonesia's Most Southern Island), East Nusa Tenggara (NTT). The implementation of this 
action research involved students and state religious colleges of two religions, namely the State Christian High School (STAKN) Kupang with the Islamic High School (STAI) Kupang. This action research activity involved 10 students from the two universities.

Collective action research was important and this activity was aimed at: 1) building interfaith cooperation among students and religious tertiary institutions in national development in $3 \mathrm{~T}$ areas (Behind, Outermost, Deepest); 2) mapping the problems of religious and religious education in the target area; 3) developing the idea of religious moderation in regional development in the $3 \mathrm{~T}$.

The results obtained from this activity, the students became accustomed to collaborating on development activities without distinguishing religions to jointly create a spirit of mutual cooperation in nation building. The benefits of this activity, the community is also given an example of the importance of togetherness regardless of ethnic background, religion, and race because with togetherness many things can be achieved faster and more strongly resolved without fussing about the differences in existing social groups.

\section{Interfaith Student Dialogue}

This activity was carried out on July 31 until August 3, 2019 at the K.M. Ngapulu, route Jakarta - Surabaya, and continued in Surabaya. Attended by 100 participants, the majority came from high school students in the Jakarta, Banten and West Java regions, and represented Hinduism, Buddhism, Catholicism, Christianity, and Islam. This activity was a continuation of the previous dialogue activity "Dialogue Cross Religious Teachers". In the previous dialogue activity, the dialogues were religious education teachers (Islam, Christianity, Catholicism, Hinduism, Buddhism, and Confucianism who teach at the high school and vocational school levels.

The religious education teachers had a dialog to formulate an action plan to develop a culture of peace through religious education in schools. Action plan for developing a peaceful culture that was designed and initiated by religious education teachers were then implemented by students in schools. The objectives of this activity were to: Develop insight into the peaceful culture of students across faiths; increase awareness and fluency of interfaith student communication; formulating Action Plans for the Development of Peace Culture in Schools; formed the Interfaith Student Communication Culture Communication Forum.

\section{Closing}

Building a culture of peace in the education space is a joint task for all Indonesian people. The strategic position of education is expected to be the center of forging a spirit of togetherness diversity. Teachers / lecturers and other academicians need to continue to mainstream "peaceful culture" in the education room. The creation of a safe, comfortable and peaceful school climate and culture is the main task and responsibility of the education community through various approaches, namely intracuricular, cocurricular and extra-curricular. Hopefully the culture of peace can continue to be encouraged especially from the education room in Indonesia.

\section{References}

[1] UNESCO, (2002), Mainsteaming Peace of Culture.Aburrahman Masud, (2019). Mendakwahkan Smiling Islam: Dialog Kemanusiaan Islam dan Barat.

[2] Jakarta. Pustaka Compass.Linda King, (2019). UNESCO's Work on Intercultural and Inter-Faith Education. Sis Subagyo Sampur Prasetyo, (2015). Pengaruh Iklim Sekolahdan SikapSiswa, Melalui Motivasi

[3] Belajarterhadap Hasil Belajar; Skripsi: Fakultas Keguruan Dan Ilmu Pendidikan Universitas Lampung.

[4] Adi Sunardi, (2012). Pengaruh Iklim Sekolah Dan Motivasi Berprestasi Siswa Terhadap Prestasi BelajarPraktik

Siswa di SMKN 2 Wonosobo; Skripsi: Pendidikan Teknik Sipil dan Perencanaan Fakultas Teknik Universitas Negeri Yogyakarta.

[5] Peraturan Pemerintah Nomor 55 tahun 2007, tentang Pendidikan Agama dan 
Pendidikan Keagamaan, pasal 1.

[6] Zuly Qodir, (2015). Fiqih Kebhinekaan: Pemikiran Islam, Multikulturalisme dan Kewargaan. Bandung:Mizan, P. 177.

[7] Biyanto, (2015). Fiqih Kebhinekaan; Berdamai dengan Perbedaan. Bandung: Mizan, pp. $271-273$.

[8] M. Tafsir, (2015). Fiqih Kebhinekaan; Fikih Relasi Sosial Antar-Umat Beragama: Keniscayaan Yang Sensitif. Bandung: Mizan, pp. $204-205$.

[9] Hayadin (2017). 'Membangun Budaya Damai berbasis Pendidikan Agama di Sekolah', Makalah: Dialog Lintas Guru Pendidikan Agama 2013-2017, Denpasar.

[10] Efa Ainul Falah (2017). Bedah Buku: Mendakwahkan Smiling Islam: Dialog Kemanusiaan Islam dan Barat.

[11] Jakarta. Puslitbang Pendidikan Agama dan Keagamaan, (2012).Laporan Kegiatan Simposium Internasional, "The Strategic Role of Religius Education in The Development of Culture of Peace.

Bogor.

[12] Puslitbang Pendidikan Agama dan Keagamaan, (2017). Laporan Kegiatan Dialog Lintas Lembaga Pendidikan Keagamaan. Jakarta. 